
literary-criticism

DOI: $10.22363 / 2312-9220-2021-26-4-739-744$

УДК 070

\title{
Pioneering Mediatization Studies: An Interview with Professor Andreas Hepp
}

\section{Пионерские исследования медиатизации}

Интервью с профессором Андреасом Хеппом

Conflicts of interest. The authors declare that there is no conflict of interest.

Article history: submitted: May 18, 2021; accepted: June 10, 2021.

For citation: Shilina, M.G., \& Hepp, A. (2021). Pioneering mediatization studies: An interview with Professor Andreas Hepp. RUDN Journal of Studies in Literature and Journalism, 26(4), 739-744. doi: 10.22363/2312-9220-2021-26-4-739-744

Заявление о конфликте интересов. Авторы заявляют об отсутствии конфликта интересов.

История статьи: поступила в редакцию - 18 мая 2021 г.; принята к публикации - 10 июня 2021 г.

Для цитирования: Shilina M.G., Hерp A. Pioneering mediatization studies: An interview with Professor Andreas Нерр // Вестник Российского университета дружбы народов. Серия: Литературоведение. Журналистика. 2021. Т. 26. № 4. С. 739-744. doi: 10.22363/ 2312-9220-2021-26-4-739-744

\section{—What does mediatization mean in your opinion?}

- Basically, mediatization is a concept to describe the relation between changes to media communications on the one hand and changes to culture and society on the other hand. This is a long-term process reaches back to when the first technical communication media were introduced. Thus, on whatever stage 
of human history you think, the kind of society people live in is in its form related to the media they use. In this sense, mediatization is - as Herbert Blumer called it - a "sensitizing concept" to make us "sensitive" to the interrelation between particular forms of societies and cultures with the forms of media and communications they are constructed by. Around this "sensitizing" concept of mediatization a group of scholars has formed to research this interrelation in detail and discuss ways of theorizing it.

Within such a general framework, we can differentiate between various "stages" of mediatization, which is the reason why Nick Couldry and I together with others have suggested the term "deep mediatization". Deep mediatization is a stage of mediatization in which the various social forms rely on digital media and infrastructures - and thereby datafication and automation of communication play an increasing role in everyday life.

\section{- Is it possible to talk about the basic relevant concept and idea of} mediatization in the 2020s?

- Today, our everyday practices are deeply entangled with digital media and their infrastructures. Therefore, media have become a crucial part of a lot of our "doings". A deeply mediatized society cannot be understood beyond digital media and their infrastructures. Just to give you one example: If you think about today's financial markets and how their "products" are traded, one realises that what we call "financial markets" could not exist beyond digital media and the computerized representation of partly automated trading. Digital media and their infrastructures are a pre-condition for the existence of financial markets as we have them nowadays.

The same can be said for other domains of society because the idea of the term deep mediatization is designed expressly to reflect this. Basically, deep mediatization is related to particular changes in our media environment, which we can systemize in five trends. The first trend is the increasing differentiation of media: more and more kinds of media are emerging along with digitalization and even "things" which we did not understand as media of communication - cars, toys etc. - have become such means of communication with the help of the internet of things. The second trend is that of increasing connectivity. Hence, all these different media are more and more interconnected by the digital infrastructures we have nowadays. Because of that interconnectedness, various forms of communication can spread across these media. The third trend is an increasing omnipresence of media. Because of mobile communications, media are increasingly accessible in any social situation. Just to take on example: While we used the fixed-line phone to call a place where we expected a certain person to be, we use the mobile phone to call this person wherever he or she is. A fourth trend is the path of innovation, which means that the waves of fundamental change in media and of the emergence of "new" media have accelerated. And finally, there is the trend of datafication: As today's media are digital, they are both means of 
communication and data collection. With all these trends the media environment is changing fundamentally.

\section{- Has your research field transformed? And, if yes, what are its main} features, especially in (pandemic) mediated reality? Are there any differences in it before/after COVID-19?

- Owing to all these trends, also my field of research — that is: mediated communication - has changed fundamentally. To address the "deepness" of today's mediatization, we need different methods that address the entanglement of media practices with digital and data processing, for example. But also our theories have to change since we have to think differently about what media of communication are and are not. Furthermore, questions of automation of communication have arisen, which I am trying to address through my research on communicative robots, in other words, systems like Alexa, Siri, but also social bots and work bots in journalism.

COVID-19 can only be understood if we understand it as deeply mediatized: At least four points can be identified here. First, from the initial outbreak, we have experienced the pandemic on the basis of mediated expectations. Films and series featuring dangerous viruses, their rapid spread and humanity's struggle with them have been popular since at least the 1970s. And for those who did not already know them, they became readily available through the various digital platforms after Covid-19 broke out. With this in mind, we approached the pandemic from existing media-mediated scripts dealing with what 'can happen' and 'how to deal with it'.

Second, we have a mediated experience of the pandemic itself: what we know about the pandemic has been communicated to us through the media, and here partially automated data journalism - the continuous visual processing of the latest Corona figures (infections, deaths, vaccinations) — has, at times, played a significant role.

Third, we are dealing with an ongoing media-mediated analysis of the course the pandemic takes. What is meant here is that digital media and their infrastructures in particular are being used to obtain "data" on how people are dealing with the pandemic. Examples of this include the analysis of people's mobility during the lockdown using login data from their mobile phones or a range of mathematical models of possible pandemic outcomes using various other digital data. Fourth and finally, we were repeatedly confronted with the idea of a media-based "solution" to individual problems brought up by the pandemic. Digital media in particular should be mentioned here, for example, when at the beginning of the pandemic politicians imagined a Covid app as the central solution strategy, digital platforms were seen as the solution to preventing a collapse of local economies and cultural industries, or when working from home was only possible through specific platforms and video conferencing systems. In all these cases, significant elements of the "solutions" were bought from Silicon Valley making these companies a lot of money even as individuals were 
becoming poorer as a result of the pandemic. Inequalities within the emerging digital society were probably made clear to all by the pandemic and in all likelihood were further exacerbated.

\section{-What are the main actors in the (pan)mediated communication model?}

- I am skeptical about all communication models that assume that they can take all levels and actors of communication into account. However, my previous reflections on COVID-19 should have made it clear that in times of deep mediatization, media and communication, research should broaden its view of the actors relevant to media communication: it is no longer enough - as with legacy media - to address journalists, contents and audiences. In my opinion, we should broaden our view also to include among others the people who develop digital media and their technologies, the people who are responsible for processing data, and audiences should rather be understood as people who use a variety of different digital media. Furthermore, questions of human-machinecommunication are gaining relevance, as the examples of communicative robots show. Of course, it is not possible for every study to take all this into account. But the subject area of media and communication studies has become much broader than it was just a few years ago.

\section{—Is mediatization really transgressive (e.g., according to "Aufhebung", etc.)? What are the problems and threats?}

- It depends on how you understand transgression. If you use the term transgression, it is close to the idea of deep mediatization in the sense that digital media are increasingly becoming entangled with everyday practices, and the construction of meaning on all levels. Media are not that "semi-independent" sphere any more as legacy media are. Digital media are present across everything. Thus, we might understand this as a "transgression" of media into everything, or what Sonya Livingstone is calling the mediation of everything.

This said, we also must be careful about such arguments: the spread of digital media and their infrastructures does not mean that the consequences are the same for all social domains. It very much depends on the domain we are looking at. Just to give you an example: You can use a data management system within a civil society organization to introduce more "inclusive" decision-making. Nevertheless, the same system can be used to introduce a more hierarchical structure of control and surveillance. Therefore, we cannot assume that there is a general "tendency" or "bias" within digital media, but we should investigate in detail how they are involved in the transformation of a particular domain.

- Which areas have been influenced by mediatization more: Culture? Society? Real or virtual world? Technologies?

- It is more about the "deepness" of entanglement between human practices and digital media and their infrastructures. This relates to culture and society in 
the same way. Also, I think it is not helpful to position a "real" world against a "virtual" one. In times of deep mediatization what is happening online is as real as what is going on offline.

From my point of view, an important basis for understanding deep mediatization is process sociology. This does not juxtapose the individual and society, but understands society as always emerging through individual practice, and that individuals are always part of society. Norbert Elias coined the term 'figuration' to capture this. A community, for example, is a figuration of people who share certain practices and orientations of meaning. One can now look at this figuration from two perspectives: From the perspective of the figuration as a whole or from the perspective of the individual as part of that figuration. This is particularly helpful for questions of autonomy. Autonomy is never absolute, but relational: it always arises in certain figurations. And then the decisive question in relation to digital media and infrastructures is: What spaces for practice do they promote for people in certain figurations? Where do they replicate previous restrictions? Where do they create new ones? From my point of view, it is this kind of relational thinking that helps.

\section{- What are the main directions for (your) future research?}

- I just finished the German translation of my latest English book "Deep mediatization". In German the book will be called "On the way to digital society". With this book I hope to shift the direction of the argument by saying that we are not yet in a "digital society" although all social domains are deeply mediatized. We are, however, on the way to being one. Therefore, it is time to think more closely about the question: What kind of digital society do we want to have? How can digital media and their infrastructures support a "good life" for as many people as possible? How should they be organized? These are questions I plan to address in my future research.

Интервью провела М.Г. Шилина / Interviewed by M.G. Shilina

\section{Bio notes:}

Marina G. Shilina, Professor, Plekhanov Russian University of Economics, Lomonosov Moscow State University, ORCID: 0000-0002-9608-352X; e-mail: marina.shilina@gmail.com

Dr Andreas Hepp is Professor of Media and Communications and Head of ZeMKI, Center for Media, Communication and Information Research, University of Bremen, Germany. He was Visiting Researcher and Professor at leading institutions such as the London School of Economics and Political Science, Goldsmiths University of London, Université Paris II Panthéon ASSAS, Stanford University and others. He is the author of 12 monographs including "The Mediated Construction of Reality" (with Nick Couldry, 2017), "Transcultural Communication" (2015) and "Cultures of Mediatization" (2013). His latest book is "Deep Mediatization" (2020). 


\section{Сведения об авторах:}

Шилина Марина Григорьевна, профессор РЭУ имени Г.В. Плеханова, МГУ имени M.В. Ломоносова, ORCID: 0000-0002-9608-352X; e-mail: marina.shilina@gmail.com

Д-р Андреас Xenn - профессор медиа и коммуникаций, руководитель Центра исследований медиа, коммуникации и информации (ZeMKI) в Бременском университете (Германия). Приглашенный исследователь, профессор таких ведущих вузов, как Лондонская школа экономики и политических наук, Лондонский университет Голдсмита, Университет Парижа II Пантеон ASSAS, Стэнфордский университет и др. Автор 12 монографий, в том числе «Культуры медиатизации» (2013), «Транскультурная коммуникация» (2015), «Медиаконструирование реальности» (совместно с Ником Кулдри, 2017), «Глубокая медиатизация» (2020). 